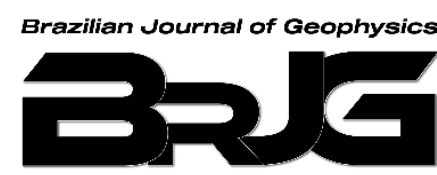

Brazilian Journal of Geophysics (2021) 39(1): 1-10

(C) 2021 Brazilian Geophysical Society

ISSN 0102-261X

DOI: 10.22564 /rbgf.v38i3.2060

\title{
METHODOLOGY FOR THE PERMEABILITY PREDICTION USING SPATIAL ENCODING OF THE MAGNETIC FIELD IN NUCLEAR MAGNETIC RESONANCE (NMR)
}

\author{
José Carlos Xavier da Silva1,2*, Giovanni Chaves Stael ${ }^{2,3}$, Silvia Lorena Bejarano Bermudez², \\ Luis Jacobo Aguilera Aguilera (iD 2,5 and Rodrigo Bagueira de Vasconcellos Azeredo iD 4
}

\begin{abstract}
We present a new formulation to determine permeability in reservoir core rocks based on the spatial encoding of the magnetic field used in the NMR technique. The variations of the magnetic field generate multiples $T_{2}$ spectra in one sample, creating a representative data of porosity distribution. In this study, each $T_{2}$ spectrum was called "magnetic cut" and the quantity depends on the length of the samples. The novel methodology was built on the assumption that the permeability in the axial direction is a linear combination of two magnetic cuts, which correspond to the maximum and minimum area, calculated from the integration of the porosity distribution in function of the transverse relaxation time. Four groups of wells were analyzed. Three were carbonates from India and Tunisia and one was sandstone from Brazil. The model was adapted to each type of formation and a specific generatrix equation was obtained for each one. The $K_{\text {oN }}$ permeability method demonstrated a good correlation to the data obtained by routine-gas analysis. In addition, the $K_{\text {oN }}$ model showed a good accuracy even when compared with classic permeability models like Timur-Coates $\mathrm{K}_{\mathrm{TC}}$ and Schlumberger-Doll Research $\mathrm{K}_{\mathrm{SDR}}$. This model could improve the determination of permeability parameters for different lithologies.
\end{abstract}

Keywords: porosity, permeability model, transverse relaxation time, magnetic cut, spatial encoding.

RESUMO. Apresentamos uma nova formulação para determinar a permeabilidade em rochas de núcleos de reservatórios com base na codificação espacial do campo magnético utilizado na técnica de RMN. As variações do campo magnético geram múltiplos espectros $T_{2}$ numa amostra, obtendo dados representativos da distribuição da porosidade. Neste estudo, cada espectro $T_{2}$ foi chamado "corte magnético" e a quantidade depende do comprimento das amostras. Esta metodologia foi construída partindo do pressuposto de que a permeabilidade no sentido axial é uma combinação linear de dois cortes magnéticos que correspondem à área máxima e mínima, calculados a partir da integração da distribuição da porosidade em função do tempo de relaxamento transversal. Foram analisados quatro grupos de poços dos quais três eram carbonatos da Índia e da Tunísia e um era de arenito do Brasil. 0 modelo foi adaptado a cada tipo de formação e foi obtida uma equação geratriz específica para cada um deles. 0 método de permeabilidade $K_{\text {oN }}$ demonstrou uma boa correlação com os dados obtidos pela análise de rotina. Além disso, o modelo $\mathrm{K}_{\mathrm{oN}}$ mostrou uma boa precisão, mesmo quando comparado com modelos clássicos de permeabilidade, como Timur-Coates $\mathrm{K}_{\mathrm{TC}}$ e Schlumberger-Doll Research $\mathrm{K}_{\mathrm{SD} \text {. }}$. Este modelo poderia melhorar a determinação dos parâmetros de permeabilidade para diferentes litologias.

Palavras-chave: porosidade, modelo de permeabilidade, tempo de relaxação transversal, corte magnético, codificação espacial.

\footnotetext{
Corresponding author: José Carlos Xavier da Silva

${ }^{1}$ Universidade do Estado do Rio de Janeiro - UERJ, Institute of Physics, Department of Quantum Electronics. R. São Francisco Xavier, 524, Bloco B, Maracanã, 20550-900 RJ, Brazil -E-mail: jcxsfis@yahoo.com.br

20bservatório Nacional - ON, Department of Geophysics, R. Gal. José Cristino, 77, 20921-400 RJ, Brazil - E-mails: stael@on.br, silviabermudez@on.br, luisjacobo@on.br

${ }^{3}$ Universidade Federal Fluminense - UFF, Institute of Geosciences, Av Gal. Milton Tavares de Souza, s/n, 24210-346 Niterói, RJ, Brazil

${ }^{4}$ Universidade Federal Fluminense - UFF, Institute of Chemistry, Outeiro de São João Batista, s/n, 24020-141 Niterói, RJ, Brazil - E-mail: rodrigo.bagueira@gmail.com

${ }^{5}$ Université de Caen Normandie - UNICAEN, École Nationale Supérieure des Ingénieurs de Caen - ENSICAEN, Centre National de la Recherche Scientifique - CNRS, Laboratoire Catalyse \& Spectrochimie - LCS, 14000 Caen, France
} 


\section{INTRODUCTION}

Studies on the characteristics of the rocks that form hydrocarbons reservoirs, water or even both are highly significant to make well drilling economically viable (Monicard, 1980). Following the decision to start drilling, a good-knowledge of the formation petrophysical properties, such as porosity and permeability, are essential (Minh et al., 2012). Porosity indicates the amount of pore spaces, and permeability represents the capacity of the rocks to transmit fluids. Determinations of the two abovementioned petrophysical parameters have an undeniable role in the evaluation of reservoir and consequently development and production planning of the oil field (Aghda et al., 2018). NMR technology, in laboratory scale and well logging, has had many applications in the oil industry from 1990 onwards, particularly for determining important parameters of rock and fluid such as porosity, fluid type, pore size distribution, permeability, bulk volume movable (BVM) and bulk volume irreducible (BVI) (Timur, 1968; Coates et al., 1991; Coates et al., 1999; Kenyon et al., 1988, Dunn et al., 1999; Behroozmand et al., 2015; Rios, 2015). This technology is able to measure porosity directly from NMR data of reservoir rocks, but to estimate permeability it is necessary to use a mathematical model. Therefore, a few models have been presented to estimate permeability (Coates et al., 1999). Two typical models using NMR $T_{2}$ data to estimate permeability in reservoir rocks are Timur-Coates (TC) model (Coates et al., 1999) and SDR permeability model (Kenyon et al., 1988).

Timur-Coates Model stands out among the most typical models of permeability (Eq. 1) (Coates et al., 1991; Coates et al., 1999; Rios, 2011; Schuab et al., 2015).

$$
K_{T C}=a\left(\frac{F F I}{B V I}\right)^{b} \phi^{c}
$$

where FFI is the Free Fluid Index, BVI is the Bound Volume Irreducible, $\phi$ is the porosity and $a, b$ and $c$ are coefficients to be determined depending on the lithology of the rocks. Classical SDR and Generalized SDR (Kenyon et al., 1988; Arns et al., 2008; Oxford Instruments, 2009; Rios, 2011) are represented by Equations $2 a$ and $2 b$.

$$
K_{\text {SDRclas }}=a \phi^{4} T_{2 L M}{ }^{2},
$$

$$
K_{\text {SDRgen. }}=a \phi^{b} T_{2 L M}{ }^{c},
$$

where $T_{2 L M}$ is the logarithmic mean value of the $T_{2}$ relaxation time distribution, the parameters $a, b$ and $c$ are coefficients to be determined depending on the lithology of the rocks, and $\phi$ is the total porosity (\%). These equations are frequently used to estimate the specific permeability in oil reservoir wells in different formations (Allen et al., 2000; Freedman, 2006; Souza et al., 2013). There are some models using Iongitudinal relaxation time $T_{1}$ (Sen et al., 1990; Elgagah et al., 1998); however, transverse relaxation time $T_{2}$ requires less operation time and the porosity response is reliable (Hürlimann et al., 1994; Sun et al., 2004; Schoenfelder et al., 2008; Souza et al., 2013).

In this paper, we proposed a novel permeability model $\left(K_{o N}\right)$ using spatial coding varying the NMR magnetic field. Multiple $T_{2}$ spectra, individually called "magnetic cut", were collected for each sample generating an image that represents the distribution of the internal porosity in the sample length (Petrov et al., 2011). After that, a Multiple Linear Regression was made for correlating it with permoporous properties. Samples of different formations and lithologies, including sandstones and carbonates, from oil wells located in India and Tunisia and from a drill well in Brazil were analyzed.

\section{MATERIALS AND METHODS}

It was studied four core rock groups of well samples collected from four different locations and formations; three of them are carbonates from India and Tunisia, and one is sandstones from Brazil. The groups were named India, Tunisia, Tunisia T and Rio Bonito (Table 1). The methods used in this paper to evaluate the properties of porosity and permeability were realized in the laboratory. The samples of reservoir rocks were analyzed by NMR, and their porosity and permeability by Nitrogen $\left(\mathrm{N}_{2}\right)$. Before routine and NMR analyses, the samples were prepared and subsequently cleaned in the Soxhlet apparatus using toluene and methanol. After that, the grain density, porosity and permeability were measured using the Corelab Autopore 500 and Autoperm 300 equipments, using $500 \mathrm{psi}$ as the standard confining pressure. These analyses were carried out at the Petrophysical Laboratory of the National Observatory (LabPetrON). 
Table 1 - Information about type, location and number of samples.

\begin{tabular}{|c|c|c|}
\hline \multirow{2}{*}{ Type } & Formations & $\begin{array}{c}\text { Number of } \\
\text { samples }\end{array}$ \\
\hline \multirow{2}{*}{ Carbonate } & India & 5 \\
\cline { 2 - 3 } & Tunisia & 7 \\
\cline { 2 - 3 } & Tunisia T & 9 \\
\hline Sandstones & Rio Bonito & 10 \\
\hline
\end{tabular}

The Rio Bonito formation was generated by a succession of cyclic sediments of sandstones, siltstones and shales, in addition to large deposits of coal found in the state of Santa Catarina, Brazil. The porosity is basically secondary, with predominance of intergranular moldic porosity, in addition to intragranular and fractures, the latter being filled with clay minerals. The carbonate samples named India, Tunisia and Tunisia T are samples of oil wells which belong to these respective countries but cannot be identified.

The cores were saturated with brine. Afterwards, NMR analyses were made using a Maran Ultra 300 NMR spectrometer by $0 x f o r d$ Instruments, operating a permanent 460 Gauss magnet equivalent to a resonance frequency of $2 \mathrm{MHz}$ for the ${ }^{1} \mathrm{H}$, with a coupled pulsed-gradient amplifier. Spatially resolved data were obtained as a function of transverse relaxation time $T_{2}$ and porosity $(\phi)$, where multiples $T_{2}$ spectra for each sample were collected and called "magnetic cut". The number of magnetic cuts depends on the length of the samples. The transverse time decay provides information about distribution of pore sizes and $T_{2}$ vs $\phi$ integral can bring information about porosity. This value was called area $A$.

We selected two specific magnetic cuts, the magnetic cut with a maximum area $\left(A_{\max }\right)$ and the magnetic cut with a minimum area $\left(A_{\min }\right)$ for each sample. As permeability is determined by the amount of fluid flowing through the rock, in the longitudinal direction, and tortuosity is a linear function of the path traveled by the fluid through the porous system (Amyx et al., 1960; Roque \& Valério, 2012), a linear combination with $A_{\max }$ and $A_{\min }$ in each formation was developed to calculate permeability, which from now on will be called $K_{\text {on, }}$ as shown in Equation 3.

$$
K_{O N}=a A_{\min }+b A_{\max }+c,
$$

where $A_{\min }$ and $A_{\max }$ are the minimum and maximum areas integrated into space $\left(\phi \times T_{2}\right)$, respectively $\left[T^{1}\right]$, and the constants $\mathrm{a}, \mathrm{b}\left(\left[L^{2} T^{-1}\right]\right)$ and $\mathrm{c}\left(\left[L^{2}\right]\right)$ are dependent on the lithology. This methodology is based on our innovate idea that the permeability in one direction could depend on the maximum and minimum porosities values inside the core, simulating a reservoir and a controller flow, respectively.

\section{RESULTS AND DISCUSSION}

As we mentioned, we applied successive variations to the NMR magnetic field to obtain different magnetic cuts along the samples. Figure 1 shows the different magnetic cuts for one representative sample of each formation that was studied. The $x$-axis represents the relaxation time distribution $T_{2}$, the $y$-axis the porosity (p.u.), and the z-axis the length of the sample. Samples from India (I-03) and Tunisia $\mathrm{T}$ (T-02), Figures 1a and 1d respectively, have almost a uniform $T_{2}$ distribution behavior in all magnetic cuts, which indicates a homogeneous distribution of pore dimensions. Tunisia $(\mathrm{BG}-1 \mathrm{~A})$ and Rio Bonito $(\mathrm{AH} 1)$ samples (Figs. $1 \mathrm{~b}$ and $1 \mathrm{c}$ respectively) have a heterogeneous pore distribution that corresponds to different pore sizes. These two samples have bigger pore sizes than the previous ones, besides being more remarkable for $\mathrm{BG}-1 \mathrm{~A}$.

\section{Determined areas in space ( $\left.\phi \times \mathrm{T}_{2}\right)$}

Calculating the areas under the curve of all distributions of $T_{2}$ throughout the sample is the basis of this new permeability formulation ( $\left.K_{\mathrm{oN}}\right)$. For each sample, it is only considered the maximum $\left(A_{\max }\right)$ and minimum $\left(A_{\min }\right)$ areas. The areas can only be compared if they belong to the same formation, and using the same experimental parameters for all samples. In Figure 2 it is possible to see a representation of the $A_{\min }$ and $A_{\max }$ values of the four samples from the regions studied. 




$1 \mathrm{a}$

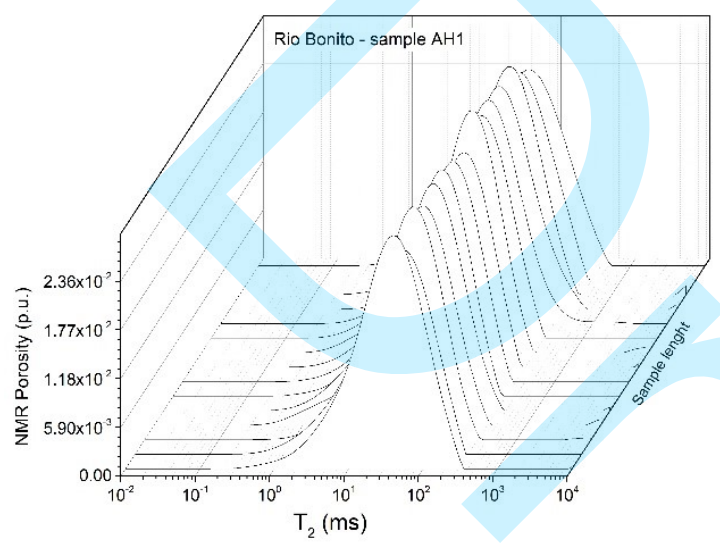

$1 \mathrm{c}$

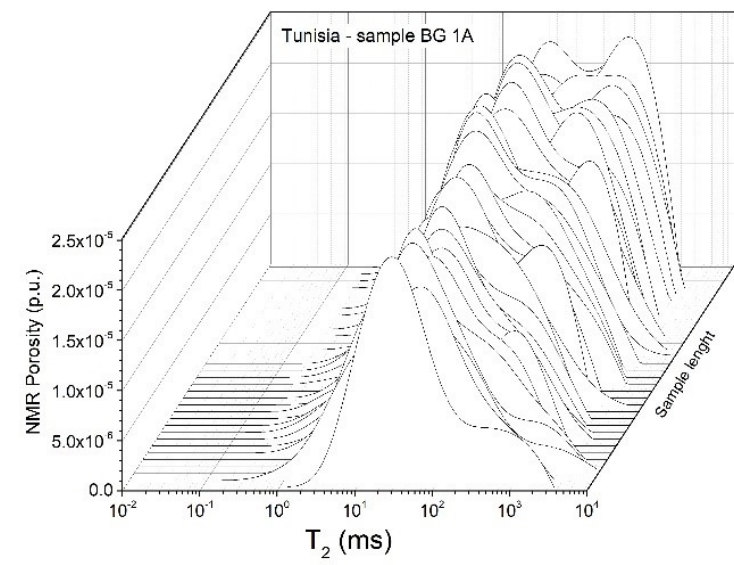

$1 \mathrm{~b}$

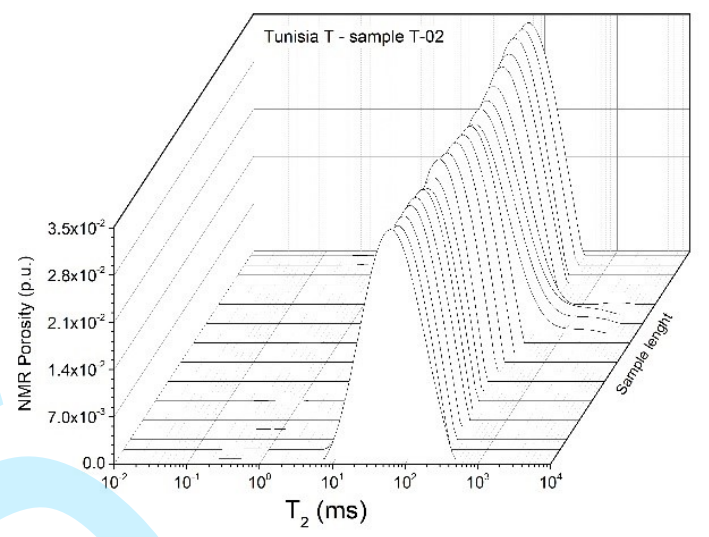

$1 d$

Figure 1 - Representation of magnetic cuts to four representative samples: a) Indian Formation, sample I-03; b) Tunisia Formation, sample BG-1A; c) Rio Bonito Formation, sample AH1; c) Tunisia T Formation, sample T-02.

\section{Generatrix equation (MLR)}

In order to calculate the coefficients $a, b$ and $c$ for each sample (see Eq. 3), a Multiple Linear Regression (MLR) was made. MLR explains the relationship between a continuous dependent variable and two or more independent variables. In this case, the dependent variable is the value of the gas permeability measured by a routine petrophysical analysis, and the independent variables are $A_{\min }$ and $A_{\max }$. The determined values of $R^{2}$ were $0.989,0.959,0.935$ and 0.927 for India, Tunisia, Rio Bonito, and Tunisia T, respectively.

The generatrix equations established for each formation after the MLR analysis are shown in Equations 4, 5,6 and 7 .
- Samples from India

$$
K_{O N}=-6.019+1.942 A_{\min }-0.509 A_{\max }
$$

- Samples from Tunisia

$$
K_{O N}=-0.28+137.04 A_{\min }-0.27 A_{\max },
$$

- Samples from Rio Bonito

$$
K_{O N}=-0.286-0.281 A_{\min }+0.292 A_{\text {max }},
$$

- Samples from Tunisia $T$

$$
K_{O N}=-2.304-0.388 A_{\min }+0.467 A_{\max },
$$





2c

$2 d$

Figure 2 - Representation of the Amin and Amax values of the four representative samples of the study formations. a) Indian Formation, sample I-03; b) Tunisia Formation, sample BG-1A; c) Rio Bonito Formation, sample AH1; c) Tunisia T Formation, sample T-02.

\section{Comparison between the calculated values for the KoN model and the experimental results, $K_{\text {gas }}$, measured in the laboratory}

A simple linear regression was made to all groups of samples in order to compare the results between the $K_{\text {on }}$ permeability model and $K_{\text {gas }}$ permeability laboratory values (Fig. 3 ). This graphic proves that there is a good relationship between the gas permeability values, measurements made in the laboratory, and the values of the permeability model implemented in this work.

The values of the determination coefficients $\left(R^{2}\right)$ and slope $(\alpha)$ are presented in Table 2. It is important to note that the values of $\mathrm{R}^{2}$ are very close to one, however, this does not guarantee a good accuracy of the model itself. It was necessary to consider the slope $(\alpha)$ to complement this information which is an important factor to analyze. If it is also very close to unity, this can indicate a better estimate of the values obtained, as it can be observed in Table 2 .

\section{Determination of percentage deviation between calculated permeability values (Kow) and laboratory measurements ( $K_{\text {gas }}$ )}

Figure 4 shows the comparison of the permeability data obtained by routine laboratory experiments and the permeability values estimated by the $K_{\text {on }}$ model for each formation. The samples from India (Fig. 4a) showed an error of approximately $\pm 5 \%$, the Tunisia samples (Fig. 4b) showed a high error variation of approximately $\pm 35 \%$. The Rio Bonito samples (Fig. 4c) indicated an error variation near $\pm 10 \%$ and the Tunisia T samples (Fig. 4d) exhibited some error values greater than $\pm 35 \%$. Figure 4 shows the adjustment of the values of the models as a function of $\mathrm{K}_{\text {gas. }}$. The samples from India and Rio Bonito show the best permeability adjustment values with errors less than $10 \%$ and $20 \%$, respectively, in relation to those from Tunisia and Tunisia $T$, and corroborated with the values of $R^{2}$ in Table 2. From the examples observed in Figure 1, it is possible to state that there is not a direct) 


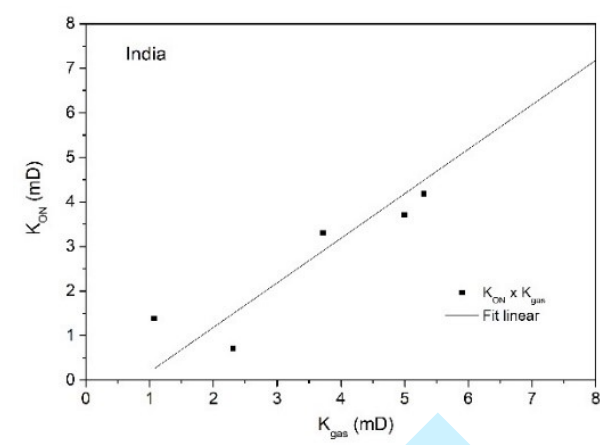

$3 a$

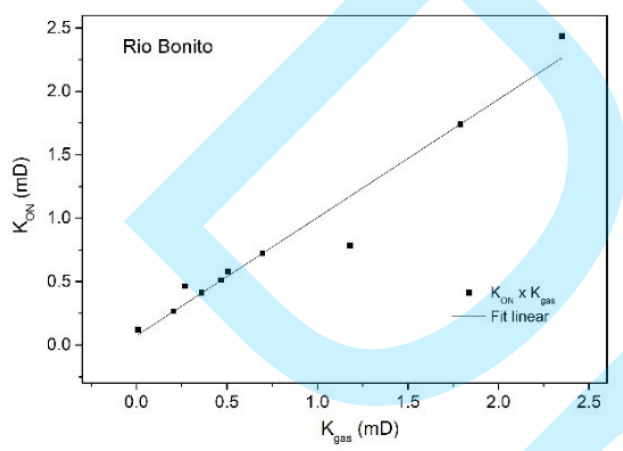

$3 \mathrm{c}$



$3 b$



$3 d$

Figure 3 - Comparison between the Kon permeability values and Kgas permeability laboratory results to all groups of samples.



$4 a$

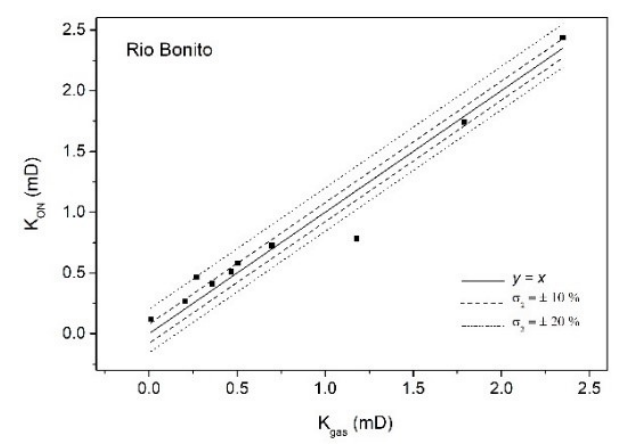

4c

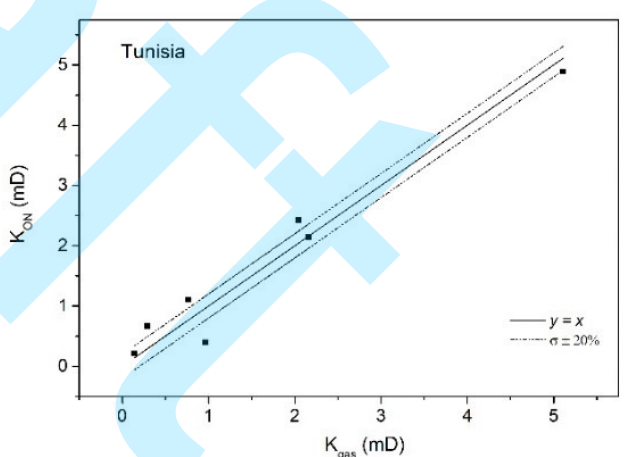

$4 b$

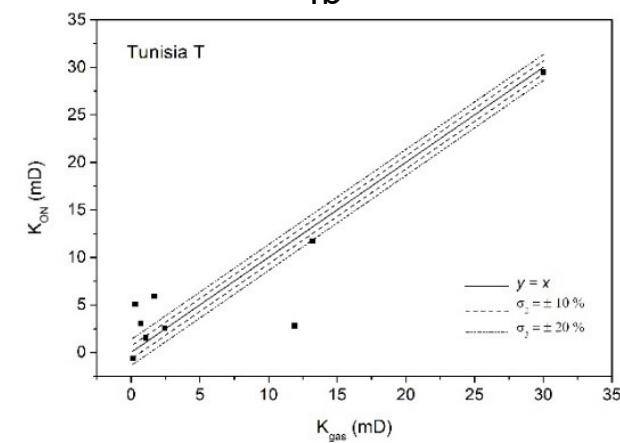

$4 d$

Figure 4 - Error limits between the $K_{o n}$ and $K_{\text {gas }}$ values for all formations. 
correspondence between the accuracy of the permeability values and the texture, which is an arrangement characteristic of each rock or formation.

Table 2 - Parameters of the linear regressions for the formations.

\begin{tabular}{|c|c|c|c|}
\hline Type & Formations & $\begin{array}{c}\text { Determination } \\
\left.\text { coefficients } \mathbf{( R}^{2}\right)\end{array}$ & $\begin{array}{c}\text { Slope } \\
(\alpha)\end{array}$ \\
\hline \multirow{2}{*}{ Carbonate } & India & 0.999 & 0.999 \\
\cline { 2 - 4 } & Tunisia & 0.949 & 0.936 \\
\cline { 2 - 4 } & Tunisia T & 0.866 & 0.881 \\
\hline \multirow{2}{*}{ Sandstone } & Rio Bonito & 0.951 & 0.932 \\
\hline
\end{tabular}

\section{Data effectiveness from the $\mathrm{K}_{\mathrm{ON}}$, Timur-Coates $\mathrm{K}_{\mathrm{TC}}$, and Schlumberger-Doll Research KSDR models}

In order to measure the accuracy of the $K_{\text {on }}$ model, the traditional Timur-Coates $\mathrm{K}_{\mathrm{Tc}}$ and Schlumberger-Doll Research $\mathrm{K}_{\mathrm{SDR}}$ models were applied to the samples and then compared with the values obtained by the $K_{\text {oN }}$ model. Some data used in these models, such as free fluid volumes, fluid irreducible ratio, porosity, and Logarithm Mean Transverse Relaxation time $\left(T_{2 L \mathrm{M}}\right)$, of the studied samples are presented in Equations 1, 2a and $2 b$, respectively. Table 3 shows $\mathrm{R}^{2}$ and the slope of the fit line, for the respective formations and models. In general, it was noticed that the $\mathrm{K}_{\mathrm{ON}}$ model presents the best fit in determining permeability, when $\mathrm{R}^{2}$ and $\alpha$ are compared. Evaluating the samples from India formation, we observed that the $K_{O N}$ and $K_{S D R}$ Classic models present good permeability estimation, with very close $\mathrm{R}^{2}$ values. However, the angular coefficient of linear adjustment of the permeability, based on the spatial encoding, is closer to the laboratory measures for this set of samples. For the carbonate and sandstone samples from the Tunisia, Tunisia T and Rio Bonito formations, the $\mathrm{K}_{\mathrm{oN}}$ model showed $\mathrm{R}^{2}$ coefficients and slopes higher than the values generated by traditional models, thus showing greater precision in the inferred permeability values when compared with experimental data.
Due to the non-viability to access the $T_{2}$ spectra of the Tunisia samples, it was not possible to obtain the Free Fluid Index (FFI) and the Irreducible Limit Volume (BVI) measurements to calculate the permeability using the TimurCoates model. In general, the Kon model presented relevant results, close to one, in determining the permeability for the varied set of samples studied.

Table 3 - Comparison indicators among the permeability models for all investigated formations.

\begin{tabular}{|c|c|c|c|c|}
\hline Type & Formation & $\begin{array}{c}\text { Permeability } \\
\text { Model }\end{array}$ & $\begin{array}{l}\text { Determination } \\
\text { coefficient }\left(\mathrm{R}^{2}\right)\end{array}$ & $\begin{array}{c}\text { Slope } \\
(\alpha)\end{array}$ \\
\hline \multirow{11}{*}{ 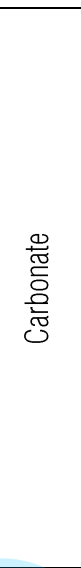 } & \multirow{4}{*}{ India } & $\begin{array}{l}\text { Generalized } \\
\text { SDR }\end{array}$ & 0.672 & 0.058 \\
\hline & & Classic SDR & 0.995 & 0.564 \\
\hline & & Timur-Coates & 0.128 & 0.028 \\
\hline & & ON & 0.999 & 0.999 \\
\hline & \multirow{3}{*}{ Tunisia } & $\begin{array}{c}\text { Generalized } \\
\text { SDR }\end{array}$ & 0.620 & 0.562 \\
\hline & & Classic SDR & 0.350 & 0.487 \\
\hline & & $\mathrm{ON}$ & 0.949 & 0.936 \\
\hline & \multirow{4}{*}{ Tunisia T } & $\begin{array}{c}\text { Generalized } \\
\text { SDR }\end{array}$ & 0.783 & 0.720 \\
\hline & & Classic SDR & 0.825 & 0.635 \\
\hline & & Timur-Coates & 0.376 & 0.528 \\
\hline & & ON & 0.866 & 0.881 \\
\hline \multirow{4}{*}{ 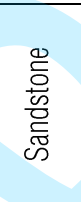 } & \multirow{4}{*}{ Rio Bonito } & $\begin{array}{c}\text { Generalized } \\
\text { SDR }\end{array}$ & 0.470 & 0.221 \\
\hline & & Classic SDR & 0.280 & 0.519 \\
\hline & & Timur-Coates & 0.001 & 0.141 \\
\hline & & $\mathrm{ON}$ & 0.951 & 0.931 \\
\hline
\end{tabular}

\section{Determination of the permeability using linear adjustment equations between $K_{\text {ON }}$ and $K_{\text {gas }}$}

A good permeability model should be able to predict the permeability of the entire formation, even when a few numbers of samples from a specific formation are used. Using the linear Equations 8 and 9, that we obtained from the comparison of the permeabilities calculated by the $\mathrm{K}_{\mathrm{ON}}$ model, with the laboratory measurements $K_{\text {gas, }}$ we estimate the permeabilities of samples from Rio Bonito and Tunisia that were not measured by NMR, as they do not have magnetic cuts data but only the $\mathrm{K}_{\text {gas }}$ measurements. Tables 4 and 5 show the calculated permeability $\left(K_{c a l}\right)$ for Rio Bonito and Tunisia, respectively. 


$$
\begin{gathered}
\mathrm{K}_{\text {cal Rio Bonito }}=\mathrm{K}_{\mathrm{ON}}=0.881 \mathrm{~K}_{\text {gas }}+0.386, \\
\mathrm{~K}_{\text {cal Tunisia }}=\mathrm{K}_{\mathrm{ON}}=0.936 \mathrm{~K}_{\text {gas }}+0.192,
\end{gathered}
$$

Table 4 shows that calculated values for permeability $\left(K_{\text {cal }}\right)$ are very close to the $K_{\text {gas }}$ experimental measurements. The most significant deviations were found in samples IV1, IV2 and IH1, which have gas permeability data very close to zero.

Table 4 - Comparison between calculated permeability ( $\left.K_{\text {cal }}\right)$ values and gas measurements of Rio Bonito samples.

\begin{tabular}{|c|c|c|}
\hline Sample & $\mathbf{K}_{\text {gas }}(\mathbf{m D})$ & $\mathbf{K}_{\text {cal }}(\mathbf{m D})$ \\
\hline AV1 & 1.18 & 1.17 \\
\hline AH1 & 0.51 & 0.54 \\
\hline AH2 & 0.91 & 0.92 \\
\hline BV1 & 2.35 & 2.26 \\
\hline BV2 & 1.13 & 1.13 \\
\hline CV1 & 0.20 & 0.26 \\
\hline CH1 & 0.27 & 0.32 \\
\hline DH1 & 0.47 & 0.51 \\
\hline DH2 & 0.55 & 0.59 \\
\hline DH3 & 2.53 & 2.43 \\
\hline EH1 & 0.36 & 0.41 \\
\hline EH2 & 0.32 & 0.37 \\
\hline EH3 & 0.38 & 0.43 \\
\hline FV1 & 0.70 & 0.72 \\
\hline FH1 & 2.85 & 2.73 \\
\hline GV1 & 0.21 & 0.27 \\
\hline GH1 & 0.40 & 0.45 \\
\hline HV1 & 1.79 & 1.74 \\
\hline HV2 & 0.67 & 0.70 \\
\hline HH1 & 10.70 & 10.04 \\
\hline IV1 & 0.00 & 0.07 \\
\hline IV2 & 0.00 & 0.07 \\
\hline IH1 & 0.00 & 0.07 \\
\hline JV1 & 0.10 & 0.16 \\
\hline JH1 & 0.55 & 0.59 \\
\hline & & \\
\hline
\end{tabular}

Table 5 shows the same analysis for Tunisia samples. It was noticed that the samples with high permeability present a better correlation between the $K_{\text {on }}$ model and the experimental data, while the samples with low permeability have a greater deviation.

Table 5 - Comparison between calculated permeability values and gas permeability measurements of the others Tunisia samples.

\begin{tabular}{|c|c|c|}
\hline Sample & $\mathbf{K}_{\text {gas }}(\mathbf{m D})$ & $\mathbf{K}_{\text {cal }}(\mathbf{m D})$ \\
\hline 1B & 0.04 & 0.19 \\
\hline 2B & 0.05 & 0.20 \\
\hline 3B & 2.50 & 2.50 \\
\hline 5B & 2.41 & 2.41 \\
\hline 6B & 8.43 & 8.05 \\
\hline $7 \mathrm{~B}$ & 3.85 & 3.76 \\
\hline 9B & 0.82 & 0.92 \\
\hline 10B & 0.16 & 0.31 \\
\hline 12B & 0.03 & 0.19 \\
\hline
\end{tabular}

\section{CONCLUSIONS}

We developed a new formulation for predicting permeability of real reservoir samples using spatial encoding of the magnetic field of the Nuclear Magnetic Resonance technique and correlating the permo-porous properties using MLR. The $K_{\text {oN }}$ model showed a good accuracy, even when compared with classic permeability models like Timur-Coates $\mathrm{K}_{\mathrm{TC}}$ and Schlumberger-Doll Research $K_{S D R}$. The determination coefficient $R^{2}$ and the slope of the adjustment line were analyzed, and the results show that both are very close to unity for the four groups of samples. Based on this information, it is possible to accurately determine the permeability values from the proposed model for different sandstone and carbonate lithologies.

The coefficients in the generatrix equations for minimum areas had a more significant influence on the determination of permeability as it is responsible for controlling the fluid flow inside the rock. The equations of linear adjustments allowed us to estimate values of permeability of other samples of the same formation that were not analyzed by NMR. 
Finally, this proposal is a good alternative, since, besides showing precise values for the permeability estimation, it provides another method for performing permeability measurements using spatial encoding of the magnetic field in the Nuclear Magnetic Resonance technique. It was also observed that the $K_{\text {on }}$ model responded better in low permeability sandstone samples than in carbonate samples.

\section{REFERENCES}

AGHDA SMF, TASLIMI M \& FAHIMIFAR A. 2018. Adjusting porosity and permeability estimation by nuclear magnetic resonance: a case study from a carbonate reservoir of south of Iran. Journal of Petroleum Exploration and Production Technology, 8: 1113-1127.

ALLEN D, FLAUM C, RAMAKRISHNAN TS, BEDFORD J, CASTELIJNS K, FAIRHURST D, GUBELIN G, HEATON N, MINH CC, NORVILLE MA, SEIM MR, PRITCHARD T \& RAMAMOORTHY R. 2000. Trends in NMR logging. Oilfield Review, 12: 2-19.

AMYX JW, BASS DMJR \& WHITING RL. 1960. Petroleum Reservoir Engineering. McGraw-Hill Book Co., New York, $610 \mathrm{pp}$.

ARNS CH, MELEÁN Y, SHEPPARD AP \& KNACKSTEDT MA. 2008. A Comparison of pore structure analysis by NMR and Xray-CT techniques. In: SPWLA 49th Annual Logging Symposium. Austin, Texas. May 25-28. SPWLA-2008NNNN.

BEHROOZMAND AA, KEATING $K$ \& AUKEN E. 2015. A Review of the Principles an Applications of the NMR Technique for Near-Surface Characterization. Surveys in Geophysics, 36: 27-85.

COATES GR, XIAO LZ \& PRAMMER MG. 1999. NMR logging principles and applications. Halliburton Energy Services, Houston: Gulf Publishing Company. 234 pp.

COATES GR, MILLER M, GILLEN M \& HENDERSON C. 1991. The MRIL in Conoco 33-1 an investigation of a new Magnetic Resonance Imaging Log. In: SPWLA 32nd Annual Logging Symposium. Midland, Texas. June 16-19. SPWLA-1991-DD.

DUNN KJ, LATORRACA GA \& BERGMAN DJ. 1999.
Permeability relation with other petrophysical parameters for periodic porous media, Geophysics, 64(2): 470-478.

ELGAGAH SA, TIAB D \& OSISANYA SO. 1998. Enhanced Reservoir Characterization Using NMR Core and Well-Log Derived Data. In: SPE Permian Basin Oil and Gas Recovery Conference. Midland, Texas. March 25-27. SPE-39810-MS.

FREEDMAN R. 2006. Advances in NMR logging. Journal of Petroleum Technology, 58(1): 60-66. SPE 89177.

HÜRLIMANN MD, HELMER KG, LATOUR LL \& SOTAK CH. 1994. Restricted Diffusion in sedimentary rocks: Determination of Surface-area-to-volume ratio and Surface Relaxivity. Journal of Magnetic Resonance, Series A, 111: 169-178.

KENYON WE, DAY PI, STRALEY C \& WILLEMSEN JF. 1988. A three-part study of NMR longitudinal relaxation properties of water saturated sandstones. SPE Formation Evaluation, 3: 622-636.

MINH C, CRARY S, ZIELINSKI L, LIU C, JONES S \& JACOBSEN S. 2012. 2D-NMR Application in Unconventional Reservoirs. In: SPE Canadian Unconventional Resources Conference. Calgary, Alberta, Canada. October 30 November 01. SPE-161578-MS.

MONICARD RP. 1980. Properties of Reservoir Rocks: Core Analysis. Institut Français du Pétrole publications. Editions Technip. Paris, France. 168 pp.

OXFORD INSTRUMENTS. 2009. Introduction to Rock Core Analysis. Molecular Biotools Ltd. Abingdon, United Kingdom. 13 pp.

PETROV OV, ERSLAND G \& BALCOM BJ. 2011. $T_{2}$ distribution mapping profiles with phase-encode MRI. Journal of Magnetic Resonance, 209: 39-46.

RIOS EH. 2011. Caracterização Petrofísica de Rochas Reservatório por RMN: Abordagem Clássica e Modelos Multivariados. Master Degree, Observatório Nacional - ON. Rio de Janeiro, RJ, Brazil, 43 pp.

RIOS EH. 2015. Estimativa da Permeabilidade de Rochas Carbonáticas por Ressonância Magnética Nuclear: Novas Abordagens. Doctorate degree, Observatório Nacional - ON. Rio de Janeiro, RJ, Brazil, 118 pp. 
ROQUE WL \& VALÉRIO FL. 2012. Estimando o Índice de Qualidade do Reservatório através de Imagens Microtomografadas de Testemunhos. In: Anais do Congresso de Matemática Aplicada e Computacional. Brazil, p. 41-44.

SCHOENFELDER W, GLASER HR, MITREITER I \& STALLMACH F. 2008. Two-dimensional NMR Relaxometry Study of Pore Space Characteristics of Carbonate Rocks from a Permian Aquifer: Journal of Applied Geophysics, 65: 21-29.

SCHUAB FB, WINTER A, TREVISAN OV \& BONZANINI LAF. 2015. NMR Log Interpretation in Bimodal Carbonate Rocks Based on Core-to-Log Integration. In: SPWLA 56 th Annual Logging Symposium. Long Beach, California. July 18-22. SPWLA-2015-K.

SEN PN, STRATLEY C, KENYON WE \& WHITTINGHAM MS. 1990. Surface-to-Volume Ratio. Charge Density, Nuclear
Magnetic Relaxation, and Rock Permeability in Clay Bearing Sandstones, Geophysics, 55(1): 61-69.

SOUZA A, CARNEIRO G, ZIELINSKI L, POLINSKI R, SCHWARTZ L, HÜRLIMANN MD, BOYD A, RIOS EH, SANTOS BCC, TREVIZAN WA, MACHADO VF \& RODRIGO BVA. 2013. Permeability Prediction Improvement Using 2D NMR Diffusion$T_{2}$ Maps. In: SPWLA 54 ${ }^{\text {th }}$ Annual Logging Symposium. New Orleans, Louisiana. June 22-26. SPWLA-2013-U.

SUN B, DUNN K-J, BILODEAU BJ, VAN DALEN SC, STONARD SW \& AL-RUSHAID A. 2004. Two-dimensional NMR Logging and Field Test Results. In: SPWLA 45 th Annual Logging Symposium. Noordwijk, Netherlands. June 6-9. SPWLA-2004-KK.

TIMUR A. 1968. An Investigation of Permeability, Porosity, \& Residual Water Saturation Relationships for Sandstone Reservoirs. The Log Analyst, 9(4): 8.

Recebido em 11 de fevereiro de 2020 / Aceito em 11 de janeiro de 2021

Received on February 11, 2020/ Accepted on January 11, 2021 